\title{
MJN FAMILY AWARENESS AND WILLINGNESS TO ACCEPT DISCHARGE PLANNING ACCORDING TO NURSING ADVOCACY PROGRAM
}

\author{
Mohamad Judha
}

Nursing Department, Faculty of Health Science, Respati Yogyakarta University, Indonesia

Corresponding Author's Email: judha.fikesunriyo@gmail.com

\begin{abstract}
Background: Planning for patients to go home raises the issue of whether the patient is ready to face health problems at home. The lack of a support system becomes a problem especially as the patient needs continuity of care both in the healing process and in maintaining the patient's health status. Research Objectives: Role of Advocacy given by Nurses with Readiness in Receiving Discharge Planning by patients and families. Research Methodology: Correlation study with cross sectional approach in which the population in this study is the family of patients who take care of their sick family member in the Internal Medicine and Surgery ward. The sampling was 97 respondents. Results: Family perceptions about the role of nurse advocacy was in the positive category (73.2\%). The level of family readiness in receiving discharge planning in the good category (53.6\%). The results of the bivariate analysis using the Spearman Rank there showed that there is relationship between family perceptions about nurse advocacy with readiness in receiving discharge planning with a $p$-value of $0.00<$ alpha 0.01 . The closeness of the relationship between family perceptions about nurse advocacy with readiness to receive discharge planning in the Inpatient Ward is in the stronger category with Coefficient Correlation (r) 0.641. This proves that family support is needed by patients to cure patients. Conclusion: Family perceptions about nurse advocacy with readiness to accept discharge planning have a strong positive relationship.
\end{abstract}

Keywords: Family, Nurses, Patients, Discharge Planning

\section{INTRODUCTION}

The characteristic of a professional nurse is having an attitude of taking responsibility for meeting the client's basic needs and being expected to be able to view the client as a unique, holistic and comprehensive being. On the basis of this holistic care a nurse understands the individual in a long range of healthy-sick concepts. Nurses must view individuals as whole beings that have complex basic needs, interrelated with one another's needs (Notoatmojo, 2003). Nursing care is also given comprehensively which means that in meeting the basic needs of the client, the nurse does not only focus on meeting physical or psychological needs, but all other aspects are the responsibility of a nurse (Kozier, 2011). Nurses' activities are carried out in a promotive, preventive, curative, and rehabilitative effort with an emphasis on primary health care to enable everyone to achieve the ability to live healthy and productive lives (Gaffar 2014).
As a care giver, nurses help clients regain their health through a process of healing that is more than just recovering from certain diseases but focuses on client health compliance holistically, including efforts to restore emotional, spiritual, and social health. Before taking nursing actions, both in assessing the client's condition, providing care and evaluating results, the nurse prepares an action plan by determining the best approach for each client. This planning is done alone by the nurse or can collaborate with the client's family. In some circumstances the nurse can also work together and consult with other health professionals (Keeling \& Ramos, 1995).

The family has a very important role in the patient's healing process, because the family is the closest support system for patients. The family must always be involved in planning, nursing, and treating patients, preparing patient's for discharge and home follow-up plans. The family must be motivated and participate actively in 
efforts to solve patient problems (Suliswati et al., 2005).

Discharge planning as a process of preparing patients to leave one service unit to transfer into another unit inside or outside a public health service agent. Discharge planning is a process where the patient begins to get health care followed by continuity of care both in the healing process and in maintaining his health status until the patient feels ready to return to his environment (Nursalam, 2002)

In Indonesia, nursing services have designed various forms of patient discharge planning formats, but most are used only in the form of documenting resume of patients returning home. These are in the form of information that must be delivered to patients going home, such as medical and non-medical interventions that have been prescribed, control schedules and nutrition requirement at home. This method is providing information targeted to patients and families just to inform and remind them. But no one can guarantee whether the patient and family know what risk factors can make the disease recur, what treatment can be done during emergencies to prevent further worsening of the patient's condition (Judha, 2016).

The role of the nurse is very important in preparing the return of the patient and role of family in the provision of discharge planning or by paying attention to the patient's problems and the care they need. The patients and family members must be taught to provide care that will must be given at home (Ester, 2005).

According to data obtained from the Medical Records section of Bantul district in November 2016, the number of patients from January to December 2015 reached 23,926 from various wards. While from January to September 2016 reached 20,509 patients. Most of the inpatient cases are Asphyxia as many as 1,505 cases, Primary hypertension as many as 943 cases, Diarrhea and Gastroenteritis as many as 908 cases, Caesarean section as many as 846 cases, Neonatal Jaundice as many as 752 cases.

From interviews with 20 families of patients treated at Panembahan Senopati Bantul District Hospital, most of the data were obtained, namely 14 families were not aware about discharge planning and several families did not know what to prepare as they did not receive any discharge plan. It can be explained that the results of interviews with several families of patients showed that majority of results have not been able to answer correctly questions related to discharge planning. Nurses have very decent family perceptions. Based on the above background, the researchers are interested in conducting the present study (Arikunto, 2002).

\section{METHODOLOGY}

This research is a correlation study, with crosssectional design. This research was conducted in several wards in Bantul district hospital. The population in this study were all families of patients who looked after their sick families in the Bantul Regency ward. The study groups consisted of 97 people based on the method of sampling of accidental sampling technique that is a sampling technique based on coincidence, i.e. anyone who accidentally or incidentally met with the researcher can be used as a sample (Notoatmojo, 2003), if it is deemed that the person found is suitable as a source of data (Notoatmojo, 2010). Inclusion criteria are the age of the patient 21-59 years, the minimum level of education of junior high school, there is a blood relationship with the patient, one patient is represented by one family, a minimum of waiting for the patient is 8 hours, the patient is responsible and willing to participate I this study. To find out the number of samples per ward, stratified random sampling technique was used and the sample results in several wards were 97 respondents.

The independent variable in this study is the family's perception of nurses. The dependent variable is readiness to accept discharge planning. The tool used for primary data collection in this study was a questionnaire. The type of statement used was in the form of a closed statement consisting of 18 questions to explore information on the perception of families about nurses who have tested the validity and 10 items to assess the level of readiness to accept discharge planning. The scale used is the Gutman scale where the research subjects were asked to answer one statement with 2 response categories namely score 2 for YES and score 1 for NO. In the family perception variable about nurses the research results are categorized into 2 categories. Positive if the answer score is between 27-36, negative if the answer score between 18-26. On the readiness variable in receiving discharge planning. The indicators used are good if the score is 17-20, Sufficient (if score 14-16), lacking (if score 10-13), Secondary data in this study are the number of patients treated from January 2015-October 2016 with 5 major cases of disease. The data processing technique is divided into 4 stages, namely editing, coding, entry, and cleaning then proceed with 
univariate analysis using frequency distribution and bivariate analysis with Spearman rank correlation.

\section{RESULTS}

\section{a. Univariate Results}

\section{Characteristics of Respondents}

Table 1: Frequency Distribution of Characteristics Based on Gender, Age, Education Level, Occupation, and Relationship with Bantul Patients Yogyakarta 2016

\begin{tabular}{|c|c|c|}
\hline Variable & Frequency (n) & Per centage $(\%)$ \\
\hline \multicolumn{3}{|c|}{ Gender } \\
\hline Man & 38 & 39.2 \\
\hline W omen & 59 & 60.8 \\
\hline Total & 97 & 100.0 \\
\hline \multicolumn{3}{|c|}{ Age } \\
\hline $21-39$ & 38 & 39.2 \\
\hline $40-59$ & 59 & 60.8 \\
\hline Total & 97 & 100.0 \\
\hline \multicolumn{3}{|c|}{ Level of education } \\
\hline Junior & 55 & 56.7 \\
\hline Senior & 33 & 34.0 \\
\hline Diploma & 3 & 3.1 \\
\hline Bachelor & 6 & 6.2 \\
\hline Total & 97 & 100.0 \\
\hline \multicolumn{3}{|c|}{ Work } \\
\hline House wife & 26 & 26.8 \\
\hline Farmer & 44 & 45.4 \\
\hline Govt. Employee & 4 & 4.1 \\
\hline Entrepreneur & 23 & 23.7 \\
\hline Total & 97 & 100 \\
\hline \multicolumn{3}{|c|}{ Status of relation with patients } \\
\hline Child & 38 & 39.2 \\
\hline Father & 25 & 25.8 \\
\hline Mother & 34 & 35.1 \\
\hline Total & 97 & 100 \\
\hline
\end{tabular}

Source: Primary data processed, 2016

Based on data from table 1, it is known that most of the respondents were female, as 59 (60.8\%). Most respondents were within the age range of $40-59$ years as many as $59(60.8 \%)$. The highest level of education among respondents was junior high, which was 55 (56.7\%). Majority of respondents work as farmers, as many as $44(45.4 \%)$. Majority of relationships were children, as many as $38(39.2 \%)$.

\section{Family Perceptions of Nurses}

In the family's perception of nurses used to determine the positive and negative results of respondents.

Table 2: Frequency Distribution of Family Perceptions of Nurses with Readiness in Receiving Discharge Planning in Bantul Yogyakarta 2016.

\begin{tabular}{|l|c|c|}
\hline $\begin{array}{l}\text { Perception } \\
\text { About nurse } \\
\text { advocacy }\end{array}$ & $\begin{array}{c}\text { Frequency } \\
\text { (n) }\end{array}$ & Percentage (\%) \\
\hline Positive & 71 & 73.2 \\
Negative & 26 & 26.8 \\
\hline Total & $\mathbf{9 7}$ & $\mathbf{1 0 0 . 0}$ \\
\hline
\end{tabular}

Source: Primary data processed, 2016

Based on table 2 it is known that most family perceptions of nurses in the positive category is 71 $(73.2 \%)$.

\section{Family Readiness in Receiving Discharge Planning}

In family readiness in receiving discharge planning is used to determine whether the readiness is good, sufficient, or lacking in respondents.

Table 3: Frequency Distribution of Family Readiness in Receiving Discharge Planning in Bantul Yogyakarta 2016.

\begin{tabular}{|l|c|c|}
\hline $\begin{array}{l}\text { Readiness to accept } \\
\text { Discharge Planning }\end{array}$ & $\begin{array}{c}\text { Frequency } \\
\text { (n) }\end{array}$ & Percentage (\%) \\
\hline Good & 52 & 53.6 \\
Sufficient & 32 & 33.0 \\
Less & 13 & 13.4 \\
\hline Total & $\mathbf{9 7}$ & $\mathbf{1 0 0 . 0}$ \\
\hline
\end{tabular}

Source: Primary data processed, 2016

Based on table 3 it is known that mostly the family readiness in accepting discharge planning falls into the good category of 52 people (53.6\%). 


\section{b. Bivariate Results}

Table 4: Cross Tabulation of Relationships between Family Perceptions of Nurses and Readiness in Receiving Discharge Planning in Bantul Yogyakarta 2016

\begin{tabular}{|c|c|c|c|c|c|c|c|c|c|c|}
\hline \multirow{3}{*}{$\begin{array}{l}\text { Perception from } \\
\text { family }\end{array}$} & \multicolumn{6}{|c|}{ Readiness in Receiving Discharge Planning } & \multirow{2}{*}{\multicolumn{2}{|c|}{ Total }} & \multirow{2}{*}{$\begin{array}{l}\text { Coef. } \\
\text { Cor }\end{array}$} & \multirow{2}{*}{$p$-Value } \\
\hline & \multicolumn{2}{|c|}{ Good } & \multicolumn{2}{|c|}{ Enough } & \multicolumn{2}{|c|}{ Less } & & & & \\
\hline & $\mathrm{f}$ & $\%$ & $\mathrm{f}$ & $\%$ & $\mathrm{~F}$ & $\%$ & $\mathrm{~F}$ & $\%$ & \multirow{4}{*}{0.641} & \multirow{4}{*}{0.00} \\
\hline Positive & 50 & 70.4 & 20 & 28.2 & 1 & 1.4 & 71 & 73.2 & & \\
\hline Negative & 2 & 7.7 & 12 & 46.2 & 12 & 46.2 & 26 & 26.8 & & \\
\hline Total & 52 & 53.6 & 32 & 33.0 & 13 & 13.4 & 97 & 100 & & \\
\hline
\end{tabular}

Source: Primary data processed, 2016

Based on Table 4, it is known that of 71 respondents $(73.2 \%)$ whose family perceptions of nurses with the positive category the majority were in readiness to receive good charge planning, as many as 50 respondents (70.4\%). The majority of family perceptions about nurses with a negative category are in readiness in accepting planning was less, as many as 12 respondents $(46.2 \%)$.

Statistical results using the Spearman Rank test showed $p$-value $0.00<$ alpha 0.01 meaning that $\mathrm{H} 0$ was rejected and Ha was accepted, namely the relationship between family perceptions of nurses and readiness to receive discharge planning at Panembahan Senopati Hospital in Bantul, Yogyakarta. Coefficient Correlation level $(r) 0.641$ shows that there is a close relationship between family perceptions about nurses and readiness to accept discharge planning.

\section{DISCUSSION}

\section{a. Family Perceptions of Nurses}

Based on table 2 it is known that the majority of family perceptions of nurses in the positive category is 71 respondents $(73.2 \%)$. The perception in this study is very constructive, it only needs to be reviewed again on how nurses provide better information to patients and their families so that when patients go home, they can apply what has been given by the nurses at the hospital.

Based on the analysis of the frequency distribution of most respondents (family) this study had a good perception of nurses in discharge planning of patients. The role of nurses in the provision of discharge planning in patients who are suffering from illness must be more optimal in order to accelerate the patient's recovery. The process of discharge planning not only involves the patient but also the family and close friends or people around the patient in order to achieve ongoing coordination of care from the hospital.
The results of this study indicate that the distribution of experimental respondent characteristics by age is that the most were aged 40-59 years i.e. 59 respondents $(60.8 \%)$, and the least were aged between 21-39 years as many as 38 respondents $(39.2 \%)$. So, most of the respondents were matured and strong enough to work and think appropriately (Nursalam, 2002). The older individual will have more experience and more mature thinking skills. The perception of this age group can be very different from the perception of other people or groups even though the situation is the same (Judha, 2016). Differences in perception can be traced to differences in personality, differences in attitudes or differences in motivation. Basically, the process of formation of this perception occurs in a person, but perception is also influenced by experience, learning process and knowledge (Supriyati, 2008).

Most of the respondents in this study group were with low education level. This can be seen from the distribution of characteristics of experimental respondents based on education as they were mostly SMP with 55 respondents $(56.7 \%)$ and D3 with only 3 respondents (3.1\%). Knowledge is obtained by a person through the learning process. So, higher the education higher will be the level of knowledge resulting in better perception (Notoatmojo, 2010).

The types of work of respondents in this study were mostly farmers with 44 respondents $(45.4 \%)$ and the least were civil servants as many as 4 respondents (4.1\%). Work also affects the level of knowledge. This can be seen in table 1 that most respondents are farmers. The farmers have less knowledge about health. High knowledge can be obtained through the facts, by seeing or hearing through communication tools such as newspapers, television, radio and other such means (Arikunto, 2002).

Based on the questionnaire, families stated that 
nurses explain about the patient's illness, nurses explain the time and how to take medication, nurses explain about activities that can and should not be done by patients, nurses always communicate with patients /families when they will take action, nurses also provide information clearly to patients /families, nurses create a comfortable atmosphere for patients / families, nurses provide advice for patient recovery, nurses provide advice on other alternative therapies to patients /families, nurses explain every action to be taken to patients /family, nurses provide motivation to patients, nurses also provide advice on therapy and treatment.

Nursing staff at Panembahan Senopati Hospital Bantul Yogyakarta at the time of discharge planning examines each patient by collecting and using related data to identify actual and potential problems, determine goals with or with patients and families, provide special measures to teach and study individually in maintaining or recovering the patient's condition optimally and evaluating continuity. Nursing care is carried out to prevent and improve the health condition of the patient, and as a member of the health team, nurses collaborate with other teams to plan, take action, coordinate and facilitate total care and also help patients achieve their main goal in improving their health status.

\section{b. Family Readiness in Receiving Discharge Planning}

The results of the frequency distribution of readiness in receiving discharge planning show that the majority of families have a good category readiness with a family number of $52(53.6 \%)$. Based on the results of the analysis of the frequency distribution, some families have a good level of readiness seen from the results of observations made from most families. The families will prevent things that can cause recurrence of the patient's disease, practice treatment of patients according to the instructions given by nurses, supervise the food consumed by patients at home, supervising patients in terms of taking medication, helping patients to move so as to accelerate healing, create a comfortable atmosphere at home for the healing of patients, praising the patients in doing positive things for faster healing, always providing motivation, and so on (Supriyati, 2008).

Based on the results of research conducted by researchers, the family's perception of nurses with readiness to receive discharge planning is positive
(73.2\%). Collaboration between nurses who are on duty in the inpatient room with the family who are waiting for patients in the hospital, where nurses provide health education such as activities that may or may not be done by the patient, explaining how to treat patients to the family, food that may be and may not be consumed by patients, and so on. Modifications are also made by the family in consultation with the nurses to facilitate and meet patient needs in terms of caring for patients. Nurses can provide information to the patient's family about better health education so that the patient's recovery is more optimal. Support and family assistance are still very much needed by patients in the healing process

Readiness is a competency means so that someone has enough readiness to do something. In conditions where one family suffers illness, the family must be better prepared to deal with a sick member in terms of recognizing the health development disorder of each family member, making the decision to take the right action, before the family can make the right decision they must be aware of the problem. health condition, the nurse must be able to assess the family's situation in order to facilitate the family in making decision (Yusnawati, 2017), provide care to family members who are sick, and who cannot help themselves because of disabilities or old age, maintain a favorable atmosphere at home for optimal health and the personal development of family members, maintaining mutual relations between family members and providing health facilities (Judha, 2017).

In the characteristics of respondents, the age factor greatly influences the family's readiness to accept discharge planning i.e higher the age the lower the physical ability of the family in caring for a sick member (Judha, 2016). It can be seen from the table that some respondents have an age range of $40-59$ years i.e. as many 59 (60.8\%). Cognitive functions like learning processes, perceptions of understanding, understanding, attention and others that cause reactions and behavior are relatively low among elderly. Psychomotor functions related to impulse like movements, actions, coordination are increasingly less deft among elderly. The level of education also influences the family's readiness to accept discharge planning so that the lower the level of education the lower is the family's readiness in caring for sick family members (Gaffar, 2014). It can be seen from the table that the highest level of education in respondents was junior high, which was 55 people (56.7\%). 
The results showed that there were still families of patients where there was lack of readiness (13.4\%). Knowledge about the importance of preparedness is still not mastered by the families due to several factors including physical condition, needs of motives and goals along with knowledge and skills.

\section{c. Relationship of Family Perception with Discharge Planning}

The results of the analysis of the relationship of family perceptions with discharge planning noted that most of the perceptions of good categories of families have a positive discharge planning level with a total family of $50(70.4 \%)$. While the category of family perception with negative family perception was as many as $12(46.2 \%)$. This shows that the family's perception of a good discharge planning can result in good planning after discharge of patients. Table 4 cross tabulation of the relationship between family perceptions with discharge planning in the inpatient ward in Bantul Yogyakarta in April 2014 shows $p$-value $0.00<$ alpha 0.1 which means that there is a relationship between family perceptions with discharge planning in Bantul Yogyakarta.

The family is a basic unit in society that has a great influence on family members because the patient's family is the most important resource in providing health services for the healing and comfort of the patient. This results in strong attachment between the family and the health status of its members. When viewed from the perspective of the community, the family is also a basic system where health and care behavior is regulated and carried out. The family provides health promotion and preventive health care for sick family members, so that the family's role in the sick family member is important to be involved in achieving optimum health (Notoatmojo. 2003; Keeling \& Ramos, 1995). That is the reason why the role of the family in sick family members is important.

Based on the questionnaire distributed, it is known that the family's perception of nurses in the positive category in dealing with sick family members has good knowledge in discharge planning. While in the hospital they realize that the patient's family has the role that is expected to be done to improve the optimization of healing, because they are a part of the treatment and patient care team (Suliswati et al., 2005). However, in this study the results of the analysis of the relationship between family perceptions and discharge planning there are still some with negative categories (Pamila, 2009).

Nurses usually explain the disease prognosis of the patient and explain the treatment procedure of the patients after the patient is discharged from the hospital. In addition, nurses also explain food that may and may not be consumed by patients, as this cannot be maintained independently by patients. This best done by the nurses because they are the treatment and care team in the hospital ward (Judha, 2017). The close relationship between family perceptions of nurses and discharge planning in the inpatient ward at Panembahan Senopati Hospital Bantul Yogyakarta which have a strong positive response indicates that there is readiness of the family and nurses in receiving discharge planning.

\section{CONCLUSIONS}

Most families have a positive perception of readiness to accept discharge planning. The majority of patients' families have preparedness in every category. There is a relationship between nurse advocacy role with readiness in receiving discharge planning by families at Panembahan Senopati Hospital Bantul Yogyakarta with strong category.

\section{Suggestions}

- For Panembahan Senopati Hospital Bantul Yogyakarta it is hoped that the role of nurses would be enhanced further in providing health care to families, especially in discharge planning in order to optimize the healing of patients.

- For nursing staff, it is expected to be able to improve nursing performance in the provision of health services or better information management that involve families in their actions as a form of collaboration.

- For future researchers, the results of this study are expected to be a source of basic information for future research on family perceptions about nurses with readiness to accept discharge planning, especially in the fields of nursing and other healthcare fields.

\section{Acknowledgement}

Acknowledgments to colleagues at the Bantul regional hospital and the PPNI commissioner of the Respati University who contributed to the study 


\section{REFERENCES}

Arikunto, S. (2002). Prosedur Penelitian Suatu Pendekatan Praktek. Jakarta: Rineka Cipta.

Ester, M. (2005). Pedoman Perawatan Pasien. Jakarta: EGC.

Gaffar, L. O. (2014). Pengantar Keperawatan Profesional. Jakarta: EGC.

Judha, M. (2016). Pengalaman Care Worker Dalam Memenuhi Kebutuhan Dasar Retardasi Mental Di Panti Asuhan. Yogyakarta: Journal Keperawatan Respati, III(1), pp 85-91

Judha, M. (2017). Pengetahuan, Pendidikan Dan Status Ekonomi Berhubungan Dengan Ketaatan Kontrol Gula Darah Pada Penderita DM Di Rsup Dr Soeradji Tirtonegoro Klaten. Yogyakarta: Journal Medika Respati, 12(February), pp 41-47.

Keeling, A.W. \& Ramos, M.C. (1995). The Role of Nursing History in Preparing Nursing for the Future," Nursing and Healthcare: Perspectives on Community, 16(1), pp 30-34.

Kozier, B. (2011). Alih Bahasa Devi Yulianti dkk. Fundamental Keperawatan. Edition 7. Jakarta: Pener'bit Buku Kedokteran EGC.

Notoatmojo, S. (2010). Metode Penelitian Kesehatan. Edtion Rev. Jakarta: Rineka Cipta.

Notoatmojo, S. (2003). Pendidikan Dan Perilaku Kesehatan. Jakarta: PT. Rineka Cipta.

Nursalam. (2002) Manajemen Keperawatan: Aplikasi dalam praktek keperawatan. $4^{\text {th }}$ edition. Jakarta: Salemba Medika.

Pemila, Uke. (2009). Internet. Konsep Discharge Planning. Diakses dari. Retrieved from: http:152.118.148.220/pkko/ fikes/konsep\%,20 DISCHARGE\% PLANNING.doc.

Suliswati, Sumijatun, Anita, T., Maruhawa, J. \& Sianturi, Y. (2005). Konsep Dasar Keperawatan Jiwa. Jakarta: EGC.

Supriyati (2008). Hubungan tingkat pengetahuan dengan sikap perawat dalam aplikasi pencegahan ansietas penderita pre operatif elektif di Rumah sakit Orthopedi Prof. Dr.R Soeharso Surakarta, penelitian. Thesis. Universitas Muhammadiyah Surakarta, Indonesia.

Yusnawati (2007). Kesiapan berwirausaha siswa jurusan kecantikan SMKN. Skripsi Yogyakarta: FT UNY. 